\title{
Komposisi Kimia Penyusun Minyak Atsiri Daun Insulin (Tithonia diversifolia (Hamsley) A.Gray) dari Kalimantan Selatan
}

\author{
Lina Fauzi'ah ${ }^{1,{ }^{*}}$, Siti Nadiya Hajati ${ }^{1}$ \\ ${ }^{1}$ Program Studi Pendidikan Kimia, Jurusan Kimia, Fakultas Matematika dan Ilmu Pengetahuan Alam, \\ Universitas Islam Indonesia \\ *email korespondensi: lina.fauziah@uii.ac.id
}

Received : 18 November 2019; Revised : 28 November 2019; Accepted : 2 Oktober 2020; Published : 10 Oktober 2020

\section{ABSTRAK}

Daun Insulin (Tithonia diversifolia) merupakan salah satu tanaman obat tradisional yang digunakan masyarakat Kalimantan Selatan untuk mengatasi glikemia. Analisis komposisi Kimia penyusun minyak atsiri dari daun Insulin yang berasal dari Kalimantan Selatan belum dilakukan. Oleh karena itu, penelitian ini bertujuan untuk menentukan komponen kimia penyusun minyak atsiri Daun Insulin ( $T$. diversifolia) untuk melengkapi data dasar daun Insulin yang diperoleh dari Kalimantan Selatan. Sampel daun Insulin diperoleh tumbuh liar dari Desa Hulu Pasar, Kabupaten Hulu Sungai Utara Kalimantan Selatan, Indonesia. Sebelum didistilasi, daun dikeringanginkan kemudian dikeringkan dengan oven pada suhu $50^{\circ} \mathrm{C}$ selama 30 menit. Metode distilasi rebus digunakan untuk mendapatkan minyak atsiri daun Insulin. Sampel didistilasi selama 48 jam sehingga diperoleh minyak bening berwarna kekuningan dengan rendemen minyak $0,02 \%(b / b)$. Minyak hasil distilasi selanjutnya dianalisis dengan Kromatografi Gas-Spektra Masa (KG-SM). Hasil kromatogram minyak atsiri daun Insulin menunjukkan adanya 6 puncak yang teridentifikasi melalui spektra massa merupakan senyawa limonen (32,14\%), $\beta$ pinen $(24,88 \%)$, $\alpha$ pinen $(21,73 \%)$, trans kariofilen $(11,68 \%)$, bisiklogermakren $(5,24 \%)$, dan $\beta$ felandren (4,33\%). Komponen kimia penyusun minyak atsiri daun Insulin termasuk dalam golongan monoterpena dan seskuiterpena hidrokarbon.

Kata-kata kunci: daun Insulin; distilasi; limonen; minyak atsiri; Tithonia diversifolia

\section{PENDAHULUAN}

Daun Insulin (Tithonia diversifolia) merupakan salah satu tanaman obat tradisional yang digunakan masyarakat untuk mengatasi glikemia. Karena khasiatnya, masyarakat Kalimantan Selatan menyebutnya dengan tanaman "Insulin" yang merujuk pada hormon yang memiliki peran pada kontrol kadar glukosa pada darah. Beberapa penelitian melaporkan tentang aktivitas biologis dari T. diversifolia yaitu antihiperglikemia (Zhao et al., 2012; Yuneldi dkk., 2018; Solfaine dkk., 2019; Rinawati dkk., 2019), biopestisida (Agboola et al., 2016), Larvasida (Wardhana \& Diana 2014), insektisida (Pulido et al., 2017), antiinflammatori (Owoyele et al., 2004; Chagas-Paula et al., 2011), antibakteri (Soetjipto dkk., 2008); dan antikanker (Kuroda et al., 2007). Ekstrak metanol dari akar titonia mengandung sesquiterpena lakton yaitu tagitinin $C$ yang memiliki aktivitas antimalaria dengan $\mathrm{IC}_{50}$ 0,706 mikrogram/mL (Goffin et al., 2002). Selain itu, ekstrak PE dari daun $T$. diversifolia juga memiliki aktivitas sitotoksik, isolat yang paling aktif terhadap sel kanker usus besar teridentifikasi sebagai Tagitinin C (Wahyuningsih, dkk., 2015). Aktivitas hiperglikemia T. diversifolia diprediksikan melalui jalur Peroxisome proliferator-activated receptors (PPARs) $y$ oleh seskuiterpena lakton (Lin, 2012). Selain itu, daun T. diversifolia juga telah dilaporkan memiliki kandungan minyak atsiri.

Minyak atsiri merupakan metabolit sekunder yang memiliki aroma khas dan telah dimanfaatkan secara luas di berbagai bidang. Aktivitas anti-oedematogenic minyak atsiri $T$. diversifolia dengan kandungan utama $\alpha$-Pinen dan $\beta$-Pinen telah dilaporkan oleh Sousa et al. (2018). Secara umum, minyak atsiri $T$. diversifolia mengandung monoterpena dan sesquiterpena hidrokarbon serta monoterpena dan seskuiterpena oksida seperti (Z)- $\beta$-ocimen (Lamaty et al., 1991), $\alpha$-Pinen (Moronkola et al., 2007), Kariofilen (Soetjipto dkk., 2008). Minyak atsiri bunga T. diversifolia (Hemsl) A. Gray memiliki kandungan utama $\alpha$-Pinene $34,42 \%$, $\beta$-Kariofilen 22,34\%, $\beta$-Pinene 11,14\%, Germacrene-D 11,13\% dan 1, 8-Cineole 8,76\% (Agboola, et al., 2016). Analisis kandungan minyak atsiri dari daun T. diversifolia yang berasal dari Kalimantan Selatan belum pernah dilakukan. Penelitian ini bertujuan untuk menentukan komposisi kimia penyusun minyak atsiri 
daun $T$. diversifolia yang berasal dari Kalimantan Selatan. Informasi tentang kandungan minyak atisri daun $T$. diversifolia diharapkan dapat menjadi acuan dalam pemanfaatan minyak atsiri tersebut.

\section{EKSPERIMEN}

\section{Alat dan Bahan}

Sampel daun Insulin diambil dari Desa Hulu Pasar, Kabupaten Hulu Sungai Utara, Kalimantan Selatan, Indonesia. Daun Insulin yang digunakan sebagai sampel diidentifikasi sebagai Tithonia diversifolia. Alat yang digunakan dalam penelitian ini adalah: oven, pestle, mortar, botol kaca, timbangan analitik Ohaus PJ1003, dan set alat destilasi rebus skala industri rumahan.

\section{Instrumen}

Kromatografi gas-spektroskopi massa (KG-SM), GCMS-QP2010 SE Shimadzu. Kondisi operasi: temperatur oven kolom $\left(60{ }^{\circ} \mathrm{C}\right)$, temperatur injeksi $\left(200{ }^{\circ} \mathrm{C}\right)$, mode injeksi (split), mode kontrol aliran (tekanan), tekanan $(36,2 \mathrm{kPa})$, total aliran $(101,3 \mathrm{~mL} / \mathrm{menit})$, aliran kolom $(0,75 \mathrm{~mL} /$ menit), velositas linear $(31,6 \mathrm{~cm} / \mathrm{s})$, start-end time $(00, .00-14.00$ menit), start-end $\mathrm{m} / \mathrm{z}(40-400)$.

\section{Prosedur Kerja}

\section{Preparasi Sampel}

Daun Insulin yang diperoleh dibersihkan, dibilas dengan air dan dikeringanginkan, kemudian dimasukkan dalam oven suhu $50{ }^{\circ} \mathrm{C}$ selama 30 menit. Sampel yang sudah kering dihaluskan dengan menggunakan pestle dan mortar hingga menjadi serbuk.

\section{Ekstraksi Minyak Atsiri menggunakan metoda Distilasi Rebus}

Seberat $1 \mathrm{Kg}$ serbuk daun Insulin kering di distilasi rebus selama 48 jam. Minyak atsiri yang diperoleh dianalisa komponen kimia penyusunnya menggunakan KG-SM.

\section{HASIL DAN DISKUSI}

Penentuan komposisi kimia dari minyak atsiri daun $T$. diversifolia telah dilakukan. Tanaman Insulin dan daun Insulin yang telah kering disajikan pada Gambar 1.

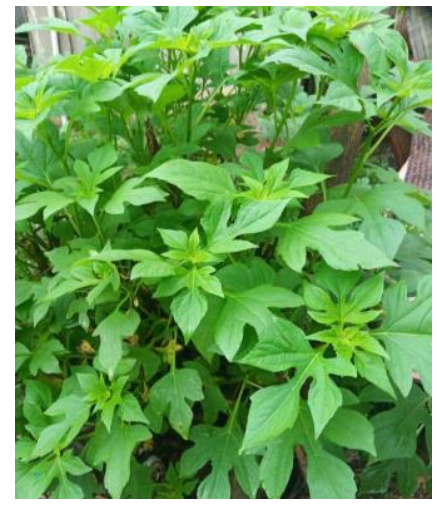

(a)

Gambar 1. Keterangan:

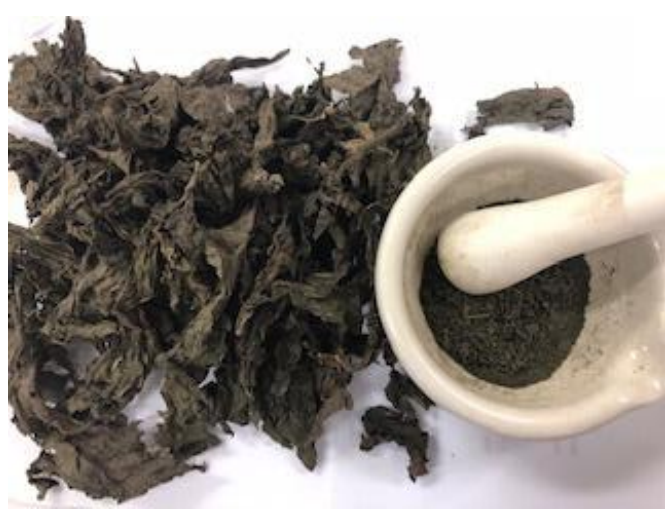

(b)

(a) Tanaman Insulin (Tithonia diversifolia)

(b) Daun Insulin kering dihaluskan dengan pastle dan mortar

Destilasi rebus daun Insulin menghasilkan rendemen minyak atsiri sebesar 0,02\% (b/b). Hasil ini mendekati rendemen dari penelitian Soetjipto, dkk. (2008), yaitu 0,054\% yang tumbuh di daerah dengan iklim yang tidak jauh berbeda. Rendemen minyak atsiri yang didapatkan, relatif lebih kecil bila dibandingkan dengan sampel dari Meksiko dengan rendemen sebesar 0,1 \% (b/b) (Moronkola et al., 2007).

Kromatogram hasil Analisa KGMS minyak atsiri disajikan pada Gambar 2. Kromatogram menunjukkan ada 6 puncak yang mengindikasikan bahwa komponen minyak atsiri sampel didominasi oleh 6 senyawa 
utama masing-masing dengan waktu retensi yang berbeda. Selanjutnya, setiap puncak yang muncul dilihat fragmentasinya dan dibandingkan dengan data Library Wiley 7 LIB dengan indeks kemiripan lebih dari $90 \%$.

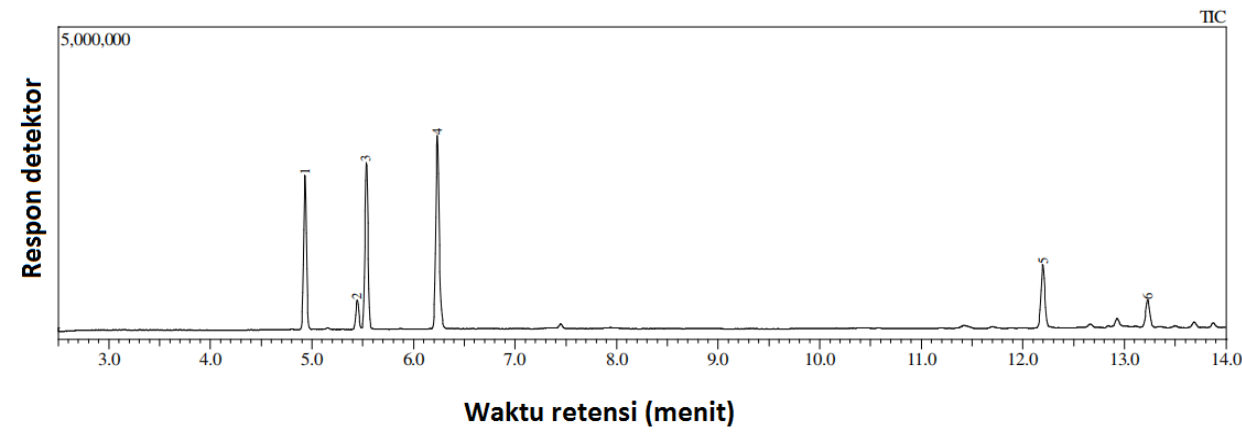

Gambar 2. Kromatogram minyak atsiri daun Insulin

Hasil analisa spektra massa puncak 4 dengan waktu retensi $\left(t_{R}\right)$ 6,26 menit disajikan pada Gambar 3(a) merupakan puncak dengan luas area terbesar. Spektra massa puncak 4 dibandingkan dengan spektra massa senyawa limonen dari Library Wiley 7 LIB pada Gambar 3(b) memiliki kemiripan dengan indeks kemiripan sebesar 99\%. Hasil interpretasi ini juga diperkuat dengan spektra massa dan fragmentasi limonen dari Attard et al. (2014). Struktur limonen terfragmentasi pada m/z: 136, 121, 107, 93,79, dan 68 (puncak dasar) sehingga diyakini bahwa puncak nomor 4 adalah limonen. Dengan cara yang sama semua puncak yang muncul diidentifikasi. Hasil identifikasi semua puncak yang muncul ditampilkan dalam Tabel 1.

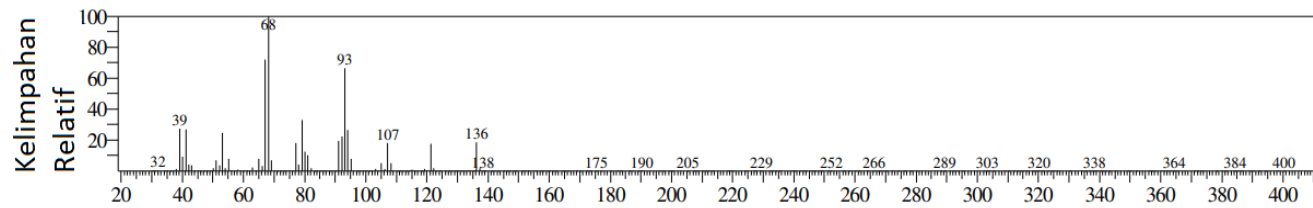

$\mathrm{m} / \mathrm{z}$

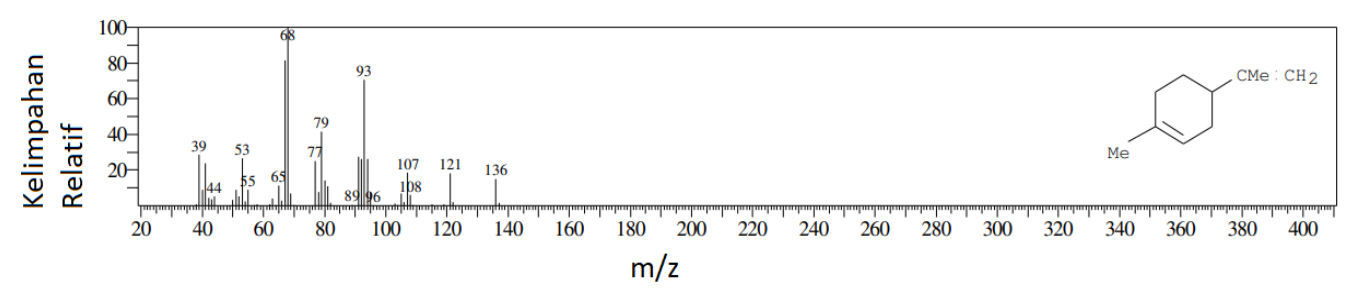

(b)

Gambar 3. Spektra massa (a) puncak 4 ( $t_{R} 6,26$ menit) (b) limonen Library Wiley 7 LIB (indeks kemiripan 99\%)

Tabel 1. Komponen kimia minyak atsiri daun insuin dengan KG-SM

\begin{tabular}{crlcccr}
\hline $\begin{array}{c}\text { No } \\
\text { Puncak }\end{array}$ & $t_{R}(\min )$ & Prediksi Senyawa & $\begin{array}{c}\text { Berat } \\
\text { Molekul }\end{array}$ & $\begin{array}{c}\text { Rumus } \\
\text { Molekul }\end{array}$ & $\begin{array}{c}\text { Similarity } \\
\text { Indeks (SI) }\end{array}$ & Kandungan Relatif (\%) \\
\hline 1 & 4,93 & $\alpha$-Pinen & 136 & $\mathrm{C}_{10} \mathrm{H}_{16}$ & 99 & 21,73 \\
2 & 5,45 & $\beta$-Felandren & 136 & $\mathrm{C}_{10} \mathrm{H}_{16}$ & 97 & 4,33 \\
3 & 5,54 & $\beta$-Pinen & 136 & $\mathrm{C}_{10} \mathrm{H}_{16}$ & 97 & 24,88 \\
4 & 6,26 & Limonen & 136 & $\mathrm{C}_{10} \mathrm{H}_{16}$ & 97 & 32,14 \\
5 & 12,20 & Trans-Kariofilen & 204 & $\mathrm{C}_{15} \mathrm{H}_{24}$ & 97 & 11,68 \\
6 & 13,23 & Bisiklogermakren & 204 & $\mathrm{C}_{15} \mathrm{H}_{24}$ & 93 & 5,24 \\
\hline
\end{tabular}

Komponen minyak atsiri hasil penelitian peneliti lain sebelumnya dapat dilihat pada Tabel 2.

Tabel 2. Beberapa hasil penelitian tentang penyusun minyak atsiri daun $T$. diversifolia

\begin{tabular}{lccccc}
\hline \multicolumn{1}{c}{ Komponen } & $\begin{array}{c}\text { Penelitian ini } \\
(\%)\end{array}$ & $\begin{array}{c}\text { Lamaty et } \\
(1991)(\%)\end{array}$ & $\begin{array}{c}\text { Moronkola, } \\
\text { et al. (2007) (\%) }\end{array}$ & $\begin{array}{c}\text { Soetjipto, } \\
\text { dkk. (2008) (\%) }\end{array}$ & $\begin{array}{c}\text { Sousa, } \\
\text { et al. 2018 (\%) }\end{array}$ \\
\hline Limonen & 32,14 & 13,90 & $\operatorname{Tr}$ & - & 4,20 \\
$\beta$-Pinen & 24,88 & 1,20 & 10,90 & - & 34,00 \\
$\alpha-$ Pinen & 21,73 & 25,00 & 32,90 & - & 45,00 \\
$\beta$-Felandren & 4,33 & - & - & - & 0,10 \\
Trans-Kariofilen & 11,68 & 2,40 & 20,80 & 28,47 & 2,50 \\
Bisiklogermakren & 5,24 & - & 2,80 & 4,90 & 0,40 \\
\hline
\end{tabular}

Keterangan: - tidak terdeteksi; tr:trace, prosentase $<0,1 \%$ 
Komponen terbesar minyak atsiri pada penelitian ini adalah limonen yang merupakan salah satu komponen utama dari penelitian Lamaty et al. (1991). Limonen terindentifikasi dalam jumlah kecil pada sampel Sousa et al. (2018), sebagai trace $(<0,1 \%)$ pada penelitian Moronkola et al. (2007) dan bahkan tidak terdeteksi pada penelitian Soetjipto dkk., (2008). Limonen merupakan monoterpenoid yang memiliki bau segar seperti lemon dan dimanfaatkan sebagai perasa atau perisa tambahan pada makanan. Limonen telah dilaporkan memiliki aktivitas antibakteri (Vuuren \& Viljoen, 2007; Zahi et al., 2015; Zahi et al., 2017).

Senyawa $\beta$-Pinen merupakan salah satu komponen utama minyak atsiri daun $T$. diversifolia dalam penelitian ini. Senyawa ini juga terdeteksi pada penelitian Sousa, et al. (2018) dan penelitian Moronkola et al. (2007), tetapi tidak ditemukan pada hasil penelitian Soetjipto dkk. (2008). Kandungan $\beta$-Pinen pada minyak atsiri dapat dipengaruhi oleh temperatur dan waktu ekstraksi, waktu (bulan) panen sampel, maupun varietas dari sampel. Sejalan dengan hasil penelitian ini, $\beta$-Pinen merupakan salah satu kandungan utama ekstrak akuabides daun T. diversifolia (Amanatie \& Sulistyowati, 2015).

Dalam penelitian ini kandungan $\beta$-Pinen dan $\alpha$-Pinen merupakan senyawa dominan kedua dan ketiga setelah limonen. Baik $\beta$-Pinen maupun $\alpha$-Pinen juga ditemukan dalam jumlah besar pada penelitian Moronkola et al., 2007) dan (Lamaty et al., 1991). Senyawa tersebut telah dilaporkan memiliki aktivitas antibakteri (Silva et al., 2012) dan antidepresan (Guzmán-Gutiérrez et al., 2015). Senyawa $\beta$-Felandren terdapat dalam jumlah kecil pada penelitian ini dan Moronkola et al. (2007). Senyawa tersebut telah dilaporkan sebagai kairomone dari suatu spesies kumbang (Miller \& Borden, 1990).

Kariofilen adalah senyawa seskuiterpena yang merupakan komponen terbesar ke dua dari sampel daun T. diversifolia pada penelitian (Moronkola, et al., 2007), sedangkan bentuk oksidanya teridentifikasi pada penelitian Soetjipto dkk. (2008). Kariofilen telah dilaporkan memiliki aktivitas antikonvulsan (Oliveira et al., 2016). Biksiklogermakren pada penelitian ini teridentifikasi dalam jumlah kecil sejalan dengan penelitian Soetjipto dkk. (2008), sedangkan isomernya, Germakren D terdapat pada sampel dari penelitian Moronkola et al. (2007). Senyawa ini telah diteliti potensinya sebagai larvasida (Govindarajan \& Benelli, 2016).

Komposisi minyak atsiri $T$. diversifolia berdasarkan penelitian ini dan sebelumnya, dapat dikategorikan menjadi minyak atsiri yang komponen penyusunnya didominasi oleh mono- dan seskuiterpena hidrokarbon. Adanya perbedaan komponen penyusun serta prosentase senyawa kimia minyak atsiri $T$. diversifolia sangat dimungkinkan terjadi karena adanya perbedaan kondisi lingkungan, ketersediaan makro dan mikro nutrient pada tanah, serta kondisi ekologis dapat mempengaruhi biosintesis kandungan kimia dari minyak atsiri $T$. diversifolia, serta metode ekstraksi yang digunakan juga ikut berperanan dalam munculnya perbedaan hasil (Sousa et al., 2018).

\section{KESIMPULAN}

Komposisi kimia penyusun minyak atsiri daun Insulin (Tithonia diversifolia) dari Kalimantan Selatan meliputi senyawa mono terpene: Limonen (32,14\%), $\beta$-Pinen (24,88\%), $\alpha$-Pinen $(21,73), \beta$-Felandren $(4,33 \%)$, serta seskuiterpena hidrokarbon: Trans-Kariofilen (11,68\%), Bisiklogermakren $(5,24 \%)$.

\section{DAFTAR PUSTAKA}

Agboola, O. O., Oyedeji, S., Olowoyo, J.O., Ajao, A., \& Aregbesola, O. (2016). Chemical composition and antimicrobial activities of essential oil extracted from Tithonia diversifolia (Asteraceae) flower. Journal of Bioresources and Bioproducts, 1(4), 169-176.

Amanatie \& Sulistyowati, E. (2015). Structure Elucidation of the Leaf of Tithonia diversifolia (Hemsl) Gray. Jurnal Sains dan Matematika, 23 (4), 101-106.

Attard,T. M., Watterson, B., Budarin, V. L., Clark, J. H., \& Hunt, J. A. (2014). Microwave assisted extraction as an important technology for valorizing orange waste. New Journal of Chemistry, 38(6), 2278-83. https://doi.org/10.1039/C4NJ00043A

Chagas-Paula, D. A., Oliveira R. B.d., Silva, V. C.d., Gobbo-Neto, L., Gasparoto, T. H., Campanelli, A. O., Faccioli, L. H., \& Costa, F. B. D. (2011). Chlorogenic acids from Tithonia diversifolia demonstrate better antiinflammatory effect than indomethacin and its sesquiterpene lactones. Journal of Ethnopharmacology, 136, 355-362. https://doi.org/10.1016/j.jep.2011.04.067 
Goffin, E., Mol., P.D., Madureira, M.d.C.d., Martins, A.P., Cunha, P.d., Philippe, G.,... Frederich, M. (2002). In vitro antiplasmodial activity of Tithonia diversifolia and identification of its main active constituent: Tagitinin C. Planta Medica, 68(6), 543-545. https://doi.org/10.1055/s-2002-32552

Govindarajan, M., \& Benelli, G. (2016). Eco-friendly larvicides from Indian plants: Effectiveness of lavandulyl acetate and bicyclogermacrene on malaria, dengue and Japanese encephalitis mosquito vectors.

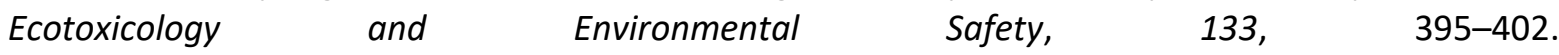
https://doi.org/10.1016/j.ecoenv.2016.07.035

Guzmán-Gutiérrez, S. L., Bonilla-Jaime, H., Gómez-Cansino, R., \& Reyes-Chilpa, R. (2015). Linalool and $\beta$ pinene exert their antidepressant-like activity through the monoaminergic pathway. Life Sciences, 128, 24-29. https://doi:10.1016/j.Ifs.2015.02.021

Kuroda, M., Yokosuka, A., Kobayashi, R., Jitsuno, M., Kando, H., Nosaka, K., Ishi, H., Yamori, T., \& Mimaki, Y. (2007). Sesquiterpenoids and Flavonoids from the Aerial Parts of Tithonia diversifolia and Their Cytotoxic Activity. Chemical and Pharmaceutical Bulletin, 55(8), 1240-1244. https://doi.org/10.1248/cpb.55.1240

Lamaty, G., Menut, C., Zollo, P.-H. A., Kuiate, J. R., Bessière, J.-M., \& Koudou, J. (1991). Aromatic Plants of Tropical Central Africa. III. Constituents of the Essential Oil of the Leaves of Tithonia diversifolia (Hemsl.) A. Gray from Cameroon. Journal of Essential Oil Research, 3(6), 399-402. https://doi:10.1080/10412905.1991.9697973

Lin, H.-R. (2012). Sesquiterpene lactones from Tithonia diversifolia act as peroxisome proliferator-activated receptor agonists. Bioorganic \& Medicinal Chemistry Letters, 22(8), 2954-2958. https://doi:10.1016/j.bmcl.2012.02.043

Miller, D.R., \& Borden, J.H. (1990). $\beta$-Phellandrene:Kairomone for Pine Engraver, Ips pini (Say) (Coleoptera: Scolytidae). Journal of Chemical Ecology, 16(8), 2519-31. https://doi.org/10.1007/BF01017475

Moronkola, D. O., Ogunwande, I. A., Walker, T. M., Setzer, W. N., \& Oyewole, I. O. (2007). Identification of the main volatile compounds in the leaf and flower of Tithonia diversifolia (Hemsl) Gray. Journal of Natural Medicines, 61(1), 63-66. https://doi:10.1007/s11418-006-0019-5

Oliveira, C. C. de, Oliveira, C. V. de, Grigoletto, J., Ribeiro, L. R., Funck, V. R., Grauncke, A. C. B., ... Oliveira, M. S. (2016). Anticonvulsant activity of $\beta$-caryophyllene against pentylenetetrazol-induced seizures. Epilepsy \& Behavior, 56, 26-31. https://doi.org/10.1016/j.yebeh.2015.12.040

Owoyele, V. B., Wuraola, C. O., Soladoye, A. O., \& Olaleye, S. B. (2004). Studies on the anti-inflammatory and analgesic properties of Tithonia diversifolia leaf extract. Journal of Ethnopharmacology, 90(2-3), 317321. https://doi:10.1016/j.jep.2003.10.010

Pulido, K. D.P., Dulcey, A. J.C., \& Martínez, J. H.I. (2017). New caffeic acid derivative from Tithonia diversifolia (Hemsl.) A. Gray butanolic extract and its antioxidant activity. Food and Chemical Toxicology, 109, 1079-1085. https://doi:10.1016/j.fct.2017.03.059

Rinawati, Suharyanto, E., dan Wijayanti, N. (2019). Pengaruh ekstrak rebusan daun Tithonia diversifolia (Hemsl.) a. Gray terhadap kadar glukosa darah. Jurnal Biotik, 7(1), 41-48. https://doi.org/10.22373/biotik.v7i1.5470

Silva, A. C. R. da, Lopes, P. M., Azevedo, M. M. B. de, Costa, D. C. M., Alviano, C. S., \& Alviano, D. S. (2012). Biological Activities of $\alpha$-Pinene and $\beta$-Pinene Enantiomers. Molecules, 17(6), 6305-6316. https://doi:10.3390/molecules17066305.

Soetjipto, H., Dewi, L., dan Prayitno, S.A. (2008). Isolasi dan identifikasi senyawa antibakteri minyak atsiri daun Kembang Bulan \{Tithonia diversifolia (Hemsley) A. Gray\}. Berita Biologi, 9(2), 155-162. 
Solfaine, R., Muniroh, L., \& Mubarokah, W.W. (2019). Efek Ekstrak Daun Tithonia diversifolia terhadap Penurunan Konsentrasi Adiponektin pada Tikus Diabetik yang Diinduksi oleh Streptozotocin. Jurnal Sain Veteriner, 7(2), 143-150. https://doi.org/10.22146/jsv.46837

Sousa, I. P., Chagas-Paula, D. A., Tiossi, R. F. J., Silva, E. de O., Miranda, M. A., de Oliveira, R. B., ... Da Costa, F. B. (2018). Essential oils from Tithonia diversifolia display potent anti-oedematogenic effects and inhibit acid production by cariogenic bacteria. Journal of Essential Oil Research, 1-10. https://doi:10.1080/10412905.2018.1500315

Vuuren, S. F. van, \& Viljoen, A. M. (2007). Antimicrobial activity of limonene enantiomers and 1,8-cineole alone and in combination. Flavour and Fragrance Journal, 22(6), 540-544. https://doi.org/10.1002/ffj.1843

Wahyuningsih, M.S.H., Wijayanti M.A., Budiyanto, A., \& Hanafi, M. (2015). Isolation and identification of potential cytotoxic compound from kembang bulan Tithonia diversifolia (Hemsley) a Gray] leaves. International Journal of Pharmacy and Pharmaceutical Sciences , 7(6), 298-301.

Wardhana, A.H., dan Diana, N. (2014). Aktivitas Biolarvasidal Ekstrak Metanol Daun Kipahit (Tithonia diversifolia) Terhadap Larva Lalat Chrysomya bezziana. Jurnal Ilmu Ternak dan Veteriner, 19(1), 4351.

Yuneldi, R. F., Saraswati, T. R., \& Yuniwarti, E. Y. W. (2018). Profile of SGPT and SGOT on Male Rats (Rattus norvegicus) Hyperglycemic After Giving Insulin Leaf Extract (Tithonia diversifolia). Biosaintifika:

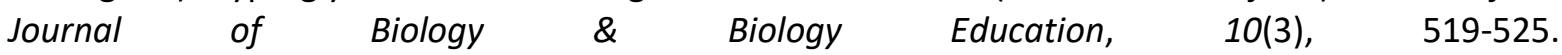
https://doi.org/10.15294/biosaintifika.v10i3.5516

Zahi, M. R., El Hattab, M., Liang, H., \& Yuan, Q. (2017). Enhancing the antimicrobial activity of d-limonene nano emulsion with the inclusion of $\varepsilon$-polylysine. Food Chemistry, 221, 18-23. https://doi.org/10.1016/j.foodchem.2016.10.037

Zahi, M. R., Liang, H., \& Yuan, Q. (2015). Improving the antimicrobial activity of d-limonene using a novel organ gel-based nano emulsion. Food Control, 50, 554-559. https://doi.org/10.1016/j.foodcont.2014.10.001

Zhao, G., Li, X., Chen, W., Xi, Z., \& Sun, L. (2012). Three new sesquiterpenes from Tithonia diversifolia and their anti-hyperglycemic activity. Fitoterapia, 83(8), 1590-1597. https://doi:10.1016/j.fitote.2012.09.007 